\title{
AN ANALYTICAL NETWORK PROCESS MODEL TO EVALUATE THE NATURE BASED DISASTERS AT TURKEY
}

\author{
Berna ULUTAS* \\ E-mail: bhaktan@,ogu.edu.tr, \\ Eskisehir Osmangazi University Department of Industrial Engineering \\ 26480 Eskisehir TURKEY \\ Mujgan SAGIR \\ Eskisehir Osmangazi University Department of Industrial Engineering \\ 26480 Eskisehir TURKEY \\ E-mail: msagir@ogu.edu.tr
}

\begin{abstract}
Disaster is an unforeseen and often sudden event that causes great damage, destruction and human suffering. They may occur in many shapes and sizes, and be grouped as they are nature based or having human origins. But the most essential thing about disasters is to be aware of their features, risk areas and consequences in order to get prepared. Due to their importance and vitality the disasters need to be investigated extensively. The nature based ones that cause risk for Turkey are the main focus of this study. Analytic Network Process (ANP) method can enable to evaluate dependency and feedback among the criteria. So, based on statistics reports and expert opinions, threatening disasters for Turkey are ranked and figured out. The prevention plans for the country are proposed related to the results.
\end{abstract}

Keywords: Nature based disasters, ANP, Disasters, Treats 